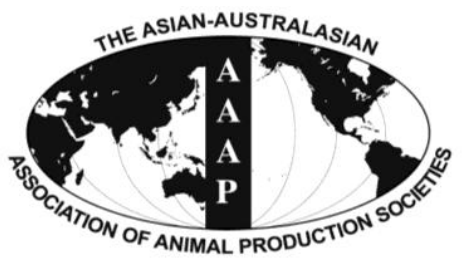

Asian Australas. J. Anim. Sci.

Vol. 26, No. 8 : 1189-1196 August 2013

http://dx.doi.org/10.5713/ajas.2013.13179

www.ajas.info

pISSN 1011-2367 elSSN 1976-5517

\title{
Zinc-chelated Vitamin C Stimulates Adipogenesis of 3T3-L1 Cells
}

\author{
Chiranjit Ghosh ${ }^{\text {a }}$, Seung Hak Yang ${ }^{\text {a }}$, Jong Geun Kim, Tae-Il Jeon ${ }^{1}$, Byung Hyun Yoon ${ }^{2}$, Jai Young Lee, \\ Eun Young $\mathrm{Lee}^{4}$, Seok Geun Choi ${ }^{5}$, and Seong Gu Hwang ${ }^{5}$ ** \\ Animal Environment Division, National Institute of Animal Science, RDA, Gyeonggi 441-706, Korea
}

\begin{abstract}
Adipose tissue development and function play a critical role in the regulation of energy balance, lipid metabolism, and the pathophysiology of metabolic syndromes. Although the effect of zinc ascorbate supplementation in diabetes or glycemic control is known in humans, the underlying mechanism is not well described. Here, we investigated the effect of a zinc-chelated vitamin $\mathrm{C}$ (ZnC) compound on the adipogenic differentiation of 3T3-L1 preadipocytes. Treatment with $\mathrm{ZnC}$ for $8 \mathrm{~d}$ significantly promoted adipogenesis, which was characterized by increased glycerol-3-phosphate dehydrogenase activity and intracellular lipid accumulation in 3T3-L1 cells. Meanwhile, $\mathrm{ZnC}$ induced a pronounced up-regulation of the expression of glucose transporter type 4 (GLUT4) and the adipocytespecific gene adipocyte protein $2(\mathrm{aP} 2)$. Analysis of mRNA and protein levels further showed that $\mathrm{ZnC}$ increased the sequential expression of peroxisome proliferator-activated receptor gamma (PPAR $\gamma$ ) and CCAAT/enhancer-binding protein alpha $(\mathrm{C} / \mathrm{EBP} \alpha)$, the key transcription factors of adipogenesis. These results indicate that $\mathrm{ZnC}$ could promote adipogenesis through $\mathrm{PPAR} \gamma$ and $\mathrm{C} / \mathrm{EBP} \alpha$, which act synergistically for the expression of aP2 and GLUT4, leading to the generation of insulin-responsive adipocytes and can thereby be useful as a novel therapeutic agent for the management of diabetes and related metabolic disorders. (Key Words: Zinc-chelated Vitamin C, Adipogenesis, PPAR $\gamma, \mathrm{C} / \mathrm{EBP} \alpha$, GLUT4, 3T3-L1)
\end{abstract}

\section{INTRODUCTION}

Type 2 diabetes mellitus (T2DM) has become a major pandemic in the last decade with a rate of 3 new cases every 10 seconds (International Diabetes Federation, Diabetes Atlas (5th edition), 2011). Obesity is considered as the most common predecessor of diabetes and cardiovascular disorders; however, lipoatrophy, i.e., the lack of adipose tissue, is also responsible for diabetes and associated metabolic disorders (Reitman et al., 2000). Adipose tissue plays an essential role in energy homeostasis, lipid

\footnotetext{
* Corresponding Author: Seong Gu Hwang. Tel: +82-31-6705050, E-mail: sghwang@hknu.ac.kr

${ }^{1}$ Department of Animal Science, College of Agriculture \& Life Science, Chonnam National University, Gwangju 500-757, Korea.

${ }^{2}$ FeedBEST CORP, Seocho-Gu, Seoul 906-3, Korea.

${ }^{3}$ Department of Chemistry, Konyang University, Nonsan 320-711, Korea.

${ }^{4}$ Department of Environmental Energy Engineering, Suwon University, Gyeonggi 445-743, Korea.

5 Department of Animal Life and Environmental Science, Hankyong National University, Anseong-si 456-749, Korea.

${ }^{a}$ These authors contributed equally to this work.

Submitted Apr. 1, 2013; Accepted May 15, 2013; Revised Jun. 4, 2013
}

metabolism, and insulin action as a metabolic and endocrine organ (Kiess et al., 2008). Previous studies have reported that an increase in the number and size of adipose tissue, especially in appropriate adipose beds, could improve its ability to store excess lipids and reduce the deleterious accumulation of triglycerides in muscle, liver, and pancreatic islets (Yamauchi et al., 2001). Accordingly, adipocytes have become a major drug target for diabetes and obesity-related metabolic disorders (Nawrocki and Scherer, 2005). Adipogenesis, the process of converting preadipocytes to mature adipocytes with the consecutive stimulation of adipogenic transcription factors such as CCAAT/enhancer-binding proteins (C/EBPs) and peroxisome proliferator-activated receptor $\gamma$ (PPAR $\gamma$ ), can also lead to the induction of insulin sensitivity (Spiegelman and Flier, 1996). Insulin acts in adipocytes by triggering a cascade of signaling events that are linked with the translocation of insulin-responsive glucose transporter 4 (GLUT4) from intracellular vesicles to the plasma membrane, allowing the uptake of glucose (Holman and Kasuga, 1997). Transcription factors such as CCAAT/enhancer-binding protein alpha $(\mathrm{C} / \mathrm{EBP} \alpha)$ and PPAR $\gamma$ act synergistically to mediate the regulation of several genes that are responsible for maintenance, creation 
of the adipocyte phenotype, and glucose and lipid metabolism, e.g., the genes for adipocyte fatty acid binding protein (aP2), GLUT4, lipoprotein lipase, and leptin (Tontonoz et al., 1994). Thiazolidinediones, which are antidiabetic agents, accelerate adipocyte differentiation, enhance insulin sensitivity, and reduce plasma glucose concentrations by increasing PPAR $\gamma$ expression (Spiegelman, 1998; Willson et al., 2001). GLUT4, which is produced during adipocyte differentiation, is tightly associated with basal and insulin-mediated glucose transport in adipocytes (Shang et al., 2007).

Zinc ascorbate $(\mathrm{ZnC})$ is a chelated compound that is produced by the combination of zinc with vitamin $\mathrm{C}$. $\mathrm{ZnC}$ is used as a dietary supplement (antioxidant and immune booster) worldwide. Diabetes patients reportedly have lower serum zinc levels due to increased urinary zinc excretion compared to normal individuals (Kinlaw et al., 1983). An infusion of vitamin $\mathrm{C}$ reportedly produces clinical improvement in DM patients (Kodama et al., 1993). A previous study reported that $\mathrm{ZnC}$ helped to improve glomerular function in T2DM patients (Farvid et al., 2005). In $\mathrm{ZnC}$, vitamin $\mathrm{C}$ is responsible for the enhancement of zinc absorption by cells, while zinc minimizes the fast oxidation of vitamin C. Although the effect of zinc and other multi-vitamin mineral supplements in diabetes or glycemic control is known in humans (Gunasekara et al., 2011; Kodama et al., 1993; May and Contoreggi, 1982; Pittas et al., 2007), the underlying mechanism is not well described. In this study, we investigated the effects of $\mathrm{ZnC}$ on adipogenesis and elucidated its molecular mechanism in 3T3-L1 cells.

\section{MATERIALS AND METHODS}

\section{Materials}

All chemicals and solvents used in the syntheses were of reagent grade and were used without further purification. Elemental analysis was carried out using a LECO CHNS932 elemental analyzer. Thermogravimetric analysis (TGA) and differential scanning calorimetry (DSC) were performed under $\mathrm{N}_{2}$ at a scan rate of $10^{\circ} \mathrm{C} / \mathrm{min}$ using a Scinco TGA 1000 thermal analyzer at Konyang University, Korea.

\section{Preparation of the zinc-chelated vitamin $\mathbf{C}$ compound}

A solution of $\mathrm{ZnSO}_{4}(330 \mathrm{~g})$ in $600 \mathrm{ml}$ water was heated to $50^{\circ} \mathrm{C}$ and $240 \mathrm{~g}$ ascorbic acid were added. The mixture was stirred for an additional $30 \mathrm{~min}$ at $70^{\circ} \mathrm{C}$. Silica gel (430 g) was then added slowly and the white mixture was dried at $40^{\circ} \mathrm{C}$ for $24 \mathrm{~h}$.

Thermogravimetric analysis and differential scanning

\section{calorimetry}

DSC and TGA of $\mathrm{ZnC}$ were obtained using a TA Instruments Scinco TGA 1000 thermal analyzer. TGA was performed with a temperature ramp of $10^{\circ} \mathrm{C} / \mathrm{min}$ and a resolution of $6.0^{\circ} \mathrm{C}$ from room temperature to $1,000^{\circ} \mathrm{C}$ in a high-purity flowing nitrogen atmosphere $\left(80 \mathrm{~cm}^{3} / \mathrm{min}\right)$. Approximately $40 \mathrm{mg}$ of sample were heated in an open platinum crucible.

\section{Cell culture and differentiation}

3T3-L1 cells were purchased from the American Type Culture Collection (Manassas, VA, USA). 3T3-L1 mouse fibroblasts were maintained in Dulbecco's modified Eagle's medium (DMEM; GIBCO BRL, USA) with $10 \%$ bovine calf serum in a humidified atmosphere containing $5 \% \mathrm{CO}_{2}$ in air at $37^{\circ} \mathrm{C}$. Two days after confluence, adipogenesis was induced using a differentiation mixture containing $10 \mu \mathrm{g} / \mathrm{ml}$ insulin, $0.25 \mu \mathrm{M}$ dexamethasone, and $0.5 \mathrm{mM}$ 3-isobutyl-1methylxanthine in DMEM containing $10 \%$ fetal bovine serum (FBS). Thereafter, the medium was changed with $10 \%$ FBS/DMEM containing $10 \mu \mathrm{g} / \mathrm{ml}$ insulin every $2 \mathrm{~d}$. The test compounds were administered at the initiation of differentiation and with every medium change for $8 \mathrm{~d}$.

\section{Cell viability assay}

Cell viability was determined using a Cell Counting Kit (CCK)-8 (Dojindo Laboratories, Japan) according to the manufacturer's instruction. Briefly, 3T3-L1 cells stimulated by the adipogenic cocktail in the absence or presence of different concentrations of $\mathrm{ZnC}(0.012$ and $0.025 \mathrm{mg} / \mathrm{ml})$ were employed for this experiment in 96-well plates. After each indicated time period, the media containing the test compounds were replaced with media containing $10 \mu \mathrm{l}$ CCK-8 reagent and incubated in the dark for $2 \mathrm{~h}$. The amount of formazan dye was measured by absorbance at $450 \mathrm{~nm}$ using an enzyme-linked immunosorbent assay microplate reader (Infinite F50; Tecan). Each assay was carried out in triplicate.

\section{Glycerol-3-phosphate dehydrogenase activity}

Glycerol-3-phosphate dehydrogenase activity (GPDH) activity was measured using a GPDH Activity Assay Kit (TaKaRa, Japan) following the manufacturer's instructions. One unit is defined as the amount of enzyme required for the consumption of $1 \mu \mathrm{mol} \mathrm{NADH}$ in $1 \mathrm{~min}$ at $30^{\circ} \mathrm{C}$. Each assay was carried out in triplicate.

\section{Oil Red $O$ staining}

Oil Red $\mathrm{O}$ staining was performed according to a modified protocol from Mizuarai and associates (Mizuarai et al., 2005). In brief, after differentiation, the cells were washed with phosphate-buffered saline (PBS) and then 
fixed with $10 \%$ formalin in PBS for $60 \mathrm{~min}$ at room temperature. The fixed cells were washed 3 times with PBS, stained with a filtered Oil Red $\mathrm{O}$ solution for $30 \mathrm{~min}$ at room temperature, and rinsed twice with distilled water. Cell morphology was assessed using an Olympus BX51 microscope with imaging software. Finally, the stained cells were destained with isopropanol and the optical density (OD) of the destaining isopropanol was measured using a spectrophotometer at a wavelength of $510 \mathrm{~nm}$.

\section{RNA extraction and CDNA synthesis}

Confluent cultures of 3T3-L1 cells in 6-well plates were induced differentiation as described previously. Total RNA was isolated from 3T3-L1 adipocytes using the RNAiso Plus Reagent (Takara, Japan). We reverse transcribed $1 \mu \mathrm{g}$ RNA using a High Capacity cDNA Reverse Transcription Kit (Applied Biosystems, USA) to obtain cDNA according to the manufacturer's protocols. Briefly, the total reaction volume was $20 \mu \mathrm{l}$ and the reaction was incubated as follows in a TC-E-96G Gene Pro (Bioer Technology, China): 10 min at $25^{\circ} \mathrm{C}, 120 \mathrm{~min}$ at $37^{\circ} \mathrm{C}, 5 \mathrm{~min}$ at $85^{\circ} \mathrm{C}$, and holding at $4{ }^{\circ} \mathrm{C}$.

\section{Real-time PCR (qPCR)}

qPCR was performed on an Applied Biosystems 7300 Real-time PCR System (Applied Biosystems, USA) using Power SYBR Green PCR Master Mix (Applied Biosystems, USA) according to the manufacturer's protocol. Briefly, PCR was performed in a final volume of $20 \mu \mathrm{l}$ including 10 ng sample cDNA, $5 \mu \mathrm{M}$ specific forward and reverse primers, and $10 \mu \mathrm{l}$ Power SYBR Green PCR Master Mix. PCR reactions consisted of an initial denaturing cycle at $95^{\circ} \mathrm{C}$ for $10 \mathrm{~min}$, followed by 40 amplification cycles: $15 \mathrm{~s}$ at $95^{\circ} \mathrm{C}$ and $1 \mathrm{~min}$ at $60^{\circ} \mathrm{C}$. The following primers were used. $\mathrm{C} / \mathrm{EBP} \alpha$ forward: TGG ACA AGA ACA GCA ACG AG; C/EBP $\alpha$ reverse: TCA CTG GTC AAC TCC AGC AC; PPAR $\gamma$ forward: GAT GGA AGA CCA CTC GCA TT; PPAR $\gamma$ reverse: AAC CAT TGG GTC AGC TCT TG; aP2 forward: ATC AGC GTA AAT GGG GAT TTG G; aP2 reverse: GTC TGC GGT GAT TTC ATC GAA; GLUT4 forward: CTT CTT TGA GAT TGG CCC TGG; GLUT4 reverse: AGG TGA AGA TGA AGA AGC CAA GC; $\beta$-actin forward: CAC CCC AGC CAT GTA CGT; and $\beta$-actin reverse: GTC CAG ACG CAG GAT GGC. The expression levels of $\mathrm{C} / \mathrm{EBP} \alpha, \operatorname{PPAR} \gamma, \mathrm{aP} 2$, and GLUT4 were normalized using $\beta$-actin as an internal control. Analysis was carried out in triplicates.

\section{Western blot analysis}

The cells were seeded in a 6-well plate and adipocyte differentiation was induced as described above. Different concentrations of $\mathrm{ZnC}(0.012$ and $0.025 \mathrm{mg} / \mathrm{ml})$ were added to the culture media at $\mathrm{d} 0$ and the media were changed as described above for $8 \mathrm{~d}$. The untreated cells consisted of identical media without $\mathrm{ZnC}$. Cell extracts were prepared by adding a protein extraction solution (iNtRON Biotechnology). The lysates were clarified by centrifugation at $28,000 \times g$ for $20 \mathrm{~min}$ at $4^{\circ} \mathrm{C}$, and the protein content of the supernatants was determined using a modified Bradford assay. The protein samples $(30 \mu \mathrm{g})$ were separated by sodium dodecyl sulfate-polyacrylamide gel electrophoresis and transferred to nitrocellulose transfer membranes (Protran; Whatman, Germany). The membranes were blocked with $5 \%$ skim milk and probed with the following primary antibodies (dilution 1:1,000): C/EBP $\alpha$ (Santa Cruz, CA, USA), PPAR $\gamma$ (Santa Cruz, CA, USA), and $\beta$-actin (Santa Cruz, CA, USA). Specific proteins were identified by further incubation of the membranes with horseradish peroxidase-conjugated secondary antibodies (1:5,000) followed by a treatment with an enhanced chemiluminescence reagent (T\&I, Korea) for $5 \mathrm{~min}$ and exposed to radiographic film (Kodak) for 1 to $10 \mathrm{~min}$.

\section{Statistical analysis}

All quantitative data are representative of at least three independent experiments. Quantitative data are presented as the mean \pm standard deviation (SD), and Tukey's post hoc least significant difference test was used to determine significance of differences among means using SAS 9.2 statistical software (Carolina, USA).

\section{RESULTS AND DISCUSSION}

\section{Thermogravimetric analysis and differential scanning calorimetry}

The thermogravimetric mass loss curve of the compound showed a multi-step decomposition profile (Figure 1). The first step, which proceeded rapidly and decayed up to $200^{\circ} \mathrm{C}$, is the dehydration step. More than half of the total weight loss due to dehydration (18.2\%) was observed below $200^{\circ} \mathrm{C}\left(5.3 \%\right.$ at $\left.95^{\circ} \mathrm{C}\right)$. The loss of organic matter from the ascorbate immediately occurred at elevated temperatures (Ünaleroğlu et al., 2002). This indicates that some of the water molecules are involved in the outer coordination sphere. Zinc and vitamin $\mathrm{C}$ concentrations merged at $28.7 \%$ and $53.1 \%$, respectively. Zinc and vitamin $\mathrm{C}$ were combined at a 1:2 ratio (Figure 2).

\section{T3-L1 cells are viable upon zinc-chelated vitamin C treatment}

To investigate the potential effects of $\mathrm{ZnC}$ on the viability and cytotoxicity of 3T3-L1 cells in the early stage of adipocyte differentiation, differentiating 3T3-L1 cells 


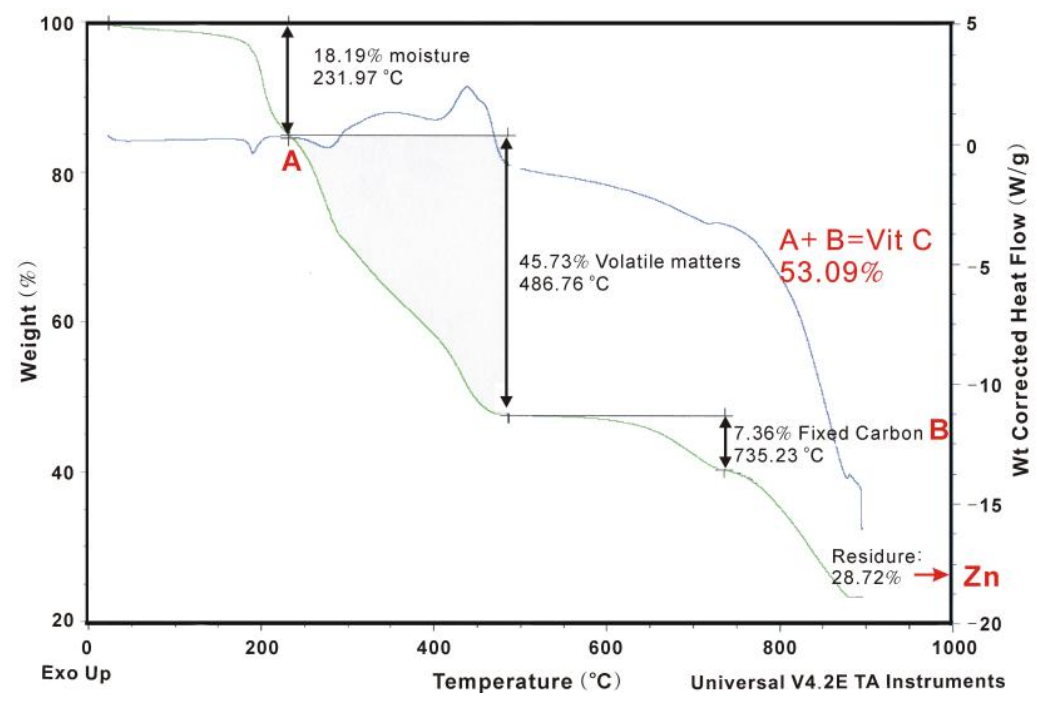

Figure 1. TGA-DSC curves of $\mathrm{ZnC}$.

were treated with different concentrations of $\mathrm{ZnC}(0,0.012$, and $0.025 \mathrm{mg} / \mathrm{ml}$ ) for 24 and $48 \mathrm{~h}$. ZnC treatment did not change the number of viable adipocytes appreciably (Figure 3 ). We can conclude that $\mathrm{ZnC}$ has no cytotoxic effect on cell viability.

\section{Zinc-chelated vitamin $\mathrm{C}$ promotes lipid accumulation in 3T3-L1 cells}

The representative images of Oil Red $\mathrm{O}$ staining demonstrated that $\mathrm{ZnC}$ promotes lipid accumulation. Adipogenesis is characterized by the successive activation of transcription factors and their downstream targets, resulting in lipid accumulation (Spiegelman and Flier, 2001); therefore, we investigated the effect of $\mathrm{ZnC}$ on the differentiation of 3T3-L1 cells. Morphological observations of cells stained with Oil Red O, a lipid stain, and OD values measured from isopropanol elution showed a significant increase in cellular lipid content with increased $\mathrm{ZnC}$ concentrations (Figure 4A and B). Furthermore, GPDH activity also supported this finding (Figure 5); the GPDH activity of all cultures treated with $\mathrm{ZnC}$ was enhanced in a dose-dependent manner.

Zinc-chelated vitamin $\mathrm{C}$ induces the expression of<smiles>O=C1OC(C(O)CO)C2=C1O[Te]1(OC3=C(O1)C(C(O)CO)C(=O)O3)O2</smiles>

Figure 2. Crystalline structure of $\mathrm{ZnC}$. adipogenic genes and promotes glucose uptake in adipocytes

Adipogenesis is governed by a complex series of transcriptional cascades that involve C/EBPs and PPAR $\gamma$, which are considered to be the key regulators of adipogenesis. $\mathrm{C} / \mathrm{EBP} \alpha$ and $\mathrm{PPAR} \gamma$ act synergistically to mediate the regulation of several genes that are responsible for the adipose phenotype and also glucose and lipid metabolism (Gregoire et al., 1998; Rosen, 2005). As ZnC promoted adipocyte differentiation, we observed the changes in the expression of $\mathrm{C} / \mathrm{EBP} \alpha$ and $\mathrm{PPAR} \gamma$ using

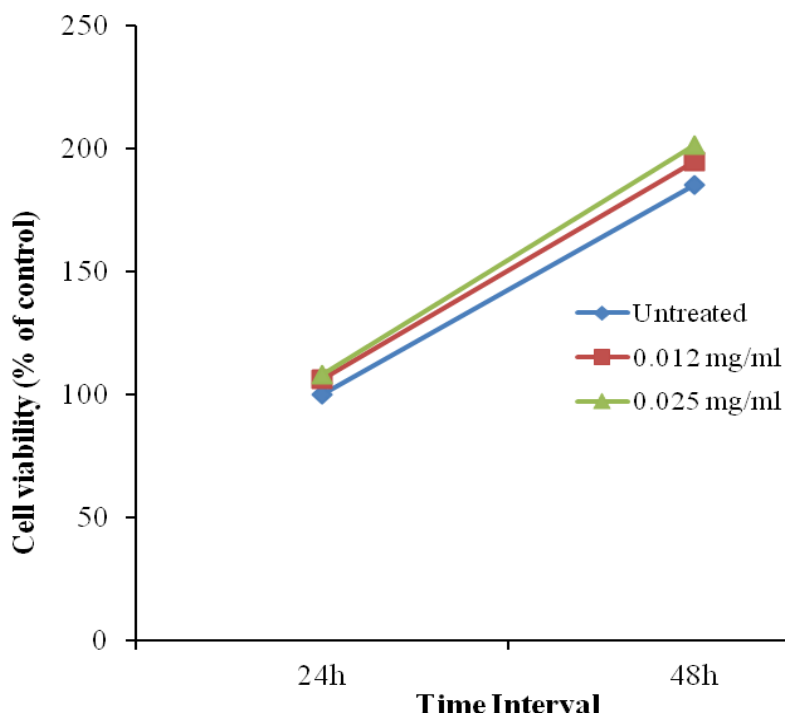

Figure 3. Effect of $\mathrm{ZnC}$ on the viability of differentiating adipocytes. Two day post-confluent 3T3-L1 cells were incubated for 24 and $48 \mathrm{~h}$ with an adipogenic cocktail and various concentrations of $\mathrm{ZnC}(0,0.012$, and $0.025 \mathrm{mg} / \mathrm{ml})$. Cell viability was monitored using a CCK-8 assay after 24 and $48 \mathrm{~h}$ of treatment. Values are expressed as the mean \pm SD of three independent experiments. 


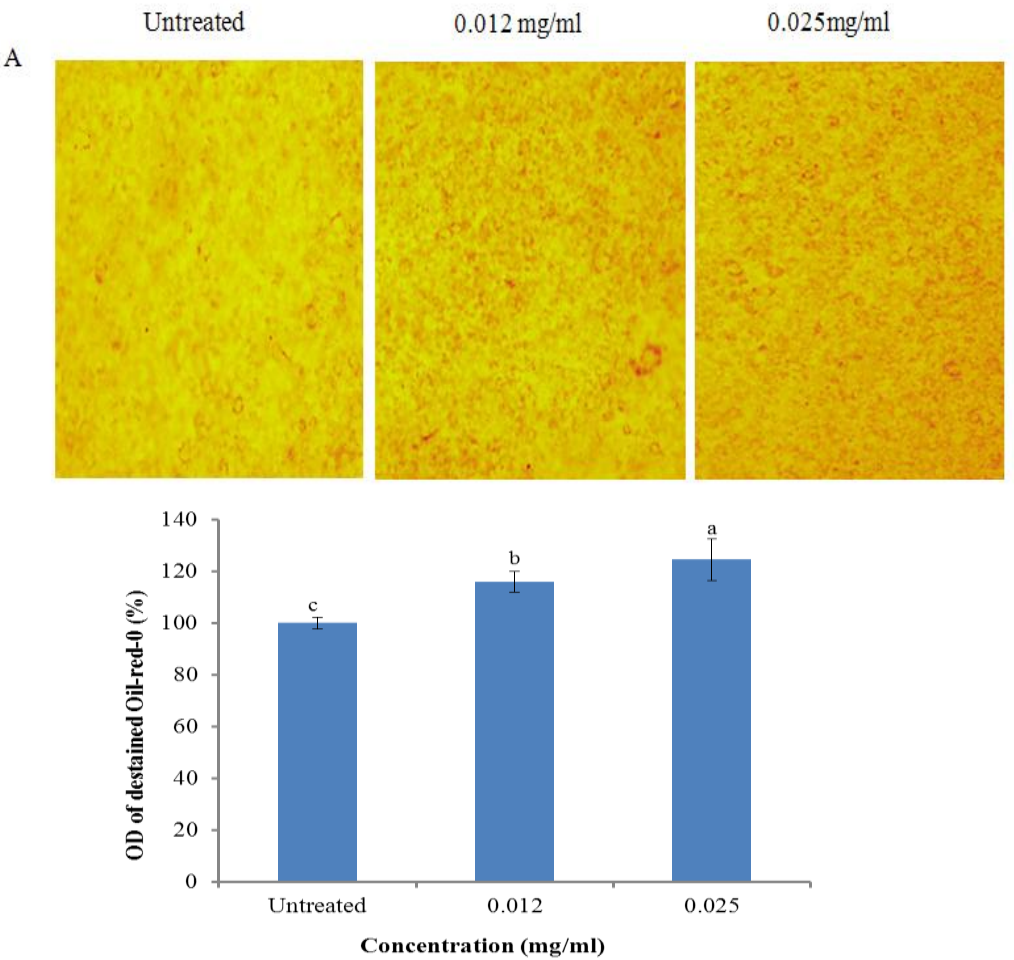

Figure 4. Representative microscopic morphological images of adipocytes stained with Oil Red O (A) and the OD values measured from isopropanol elution of Oil Red O staining (B) after $8 \mathrm{~d}$ of differentiation. Preadipocytes were cultured in growth medium until they reached confluence and the quiescent cells were then incubated in differentiation medium (DM) and post-DM with $0,0.012$, and 0.025 $\mathrm{mg} / \mathrm{ml} \mathrm{ZnC}$. At d 8 post-induction, Oil Red O staining was performed and images were taken at $10 \times$ magnification. Finally, the cells were destained with isopropanol and the OD of the destaining isopropanol was measured using spectrophotometry at a wavelength of $510 \mathrm{~nm}$. Values are expressed as the mean $\pm \mathrm{SD}$ of three independent experiments. Bars within the same panel with different letters are significantly different $(\mathrm{p}<0.001)$.

qPCR. ZnC significantly increased the mRNA levels of (Wu et al., 1999). ZnC also significantly induced the $\mathrm{C} / \mathrm{EBP} \alpha$ and PPAR $\gamma$ (Figure 6A and B). ZnC markedly expression of GLUT4, which serves a vital role in insulininduced the expression of $\mathrm{aP} 2$, a target gene of PPAR $\gamma$ and a mediated glucose transport (Figure 6D), suggesting that marker of late differentiation in adipocytes (Figure 6C). $\mathrm{ZnC}$ treatment can enhance glucose uptake in $\mathrm{C} / \mathrm{EBP} \alpha$ plays a significant role in the regulation of GLUT4 differentiating adipocytes. and other genes involved in the metabolic actions of insulin

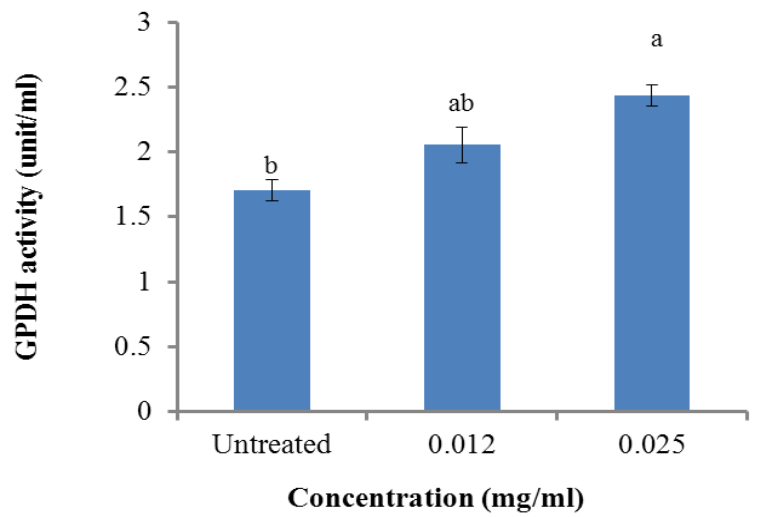

Figure 5. GPDH activity of the adipocytes on d 8 of differentiation. Preadipocytes were cultured in growth medium until they reached confluence and the quiescent cells were then incubated in DM and post-DM with $0,0.012$, and $0.025 \mathrm{mg} / \mathrm{ml} \mathrm{ZnC}$. At $\mathrm{d} 8$ post-induction, proteins were collected and GPDH analysis was performed. Values are expressed as the mean \pm SD of three independent experiments. Bars within the same panel with different letters are significantly different $(\mathrm{p}<0.001)$. 
A
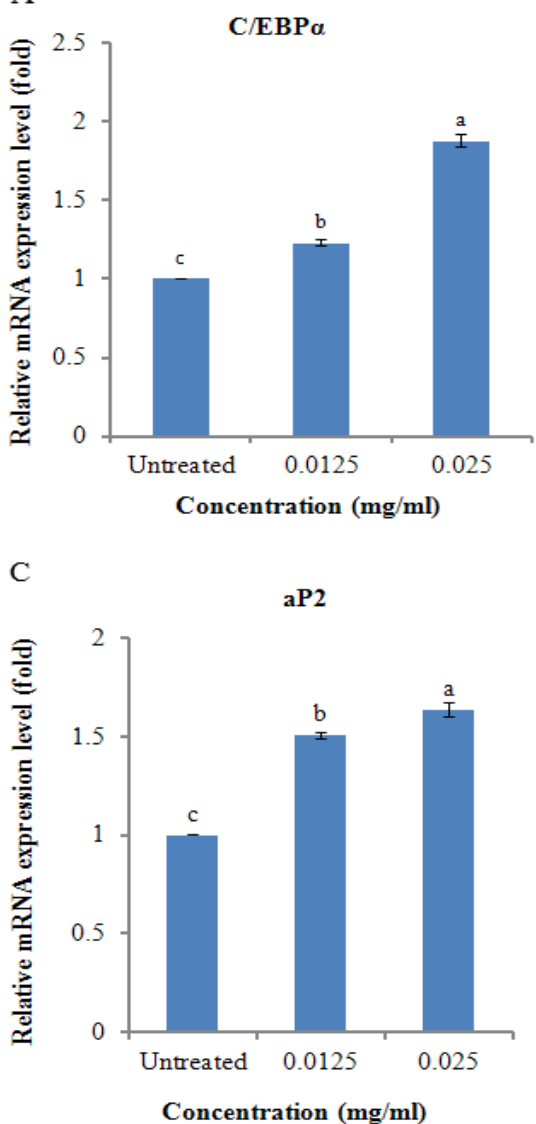

B

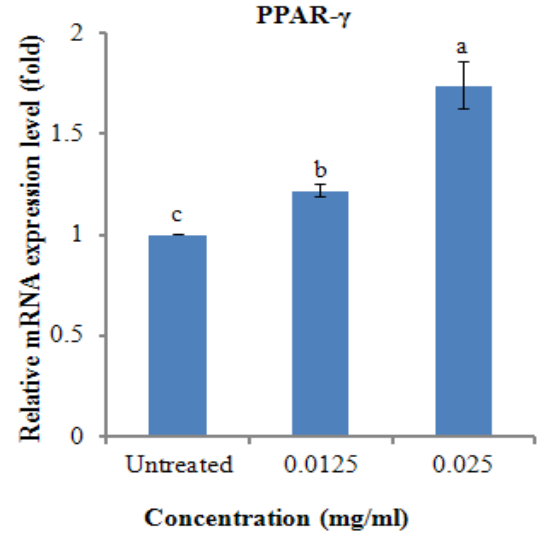

$\mathrm{D}$

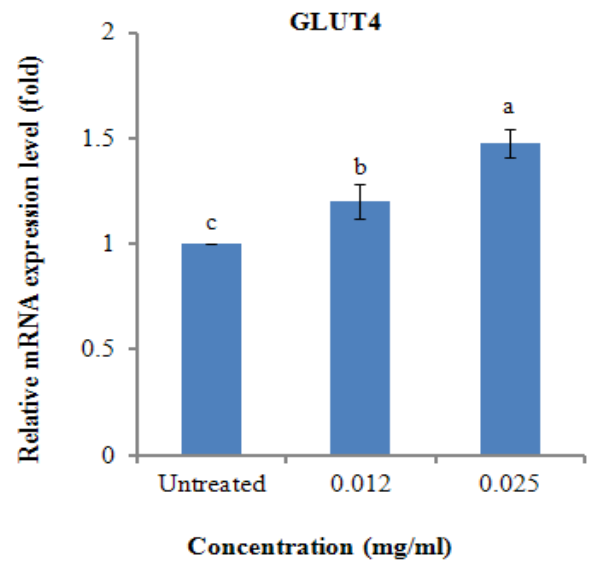

Figure 6. Effects of $\mathrm{ZnC}$ on the expression of genes associated with adipocyte differentiation. Post-confluent 3T3-L1 preadipocytes (d 0) were treated with different concentration of $\mathrm{ZnC}(0,0.012$, and $0.025 \mathrm{mg} / \mathrm{ml})$ every $2 \mathrm{~d}$ for 8 days. On $\mathrm{d} 8$, total cellular RNA was isolated from 3T3-L1 cells. The expression levels of (A) C/EBP $\alpha$, (B) PPAR $\gamma,(\mathrm{C}) \mathrm{aP} 2$, and (D) GLUT4 were quantified by qPCR. Gene expression was normalized using $\beta$-actin as an internal control. Each bar represents the mean \pm SD of three independent experiments. Bars within the same panel with different letters are significantly different $(\mathrm{p}<0.001)$.

\section{Zinc-chelated vitamin $\mathrm{C}$ enhances the protein expression of $\mathrm{C} / \mathrm{EBP} \alpha$ and PPAR $\gamma$}

$\mathrm{C} / \mathrm{EBP} \alpha$ and PPAR $\gamma$ are considered to be the most critical factors for adipogenesis. Generally, most of the transcriptional regulators of adipogenesis operate in a "feed-forward" fashion, whereby they induce other proadipogenic factors and then act in concert with those factors to promote downstream gene expression. PPAR $\gamma$ initially induces the expression of the adipogenic transcription factor $\mathrm{C} / \mathrm{EBP} \alpha$ and then binds with $\mathrm{C} / \mathrm{EBP} \alpha$ to the promoter/enhancer of the gene encoding aP2 (Green and Kehinde, 1976; Ross et al., 1990; Rosen, 2005). PPAR $\gamma$ and $\mathrm{C} / \mathrm{EBP} \alpha$ act synergistically to generate fully differentiated, insulin-responsive adipocytes (Tontonoz et al., 1994; Wu et al., 1999). Previous studies reported that zinc possesses insulin like action and Vit $\mathrm{C}$ promotes adipogenesis via increasing the growth rate and inducing differentiation in 3T3-L1 cells (May and Contoreggi, 1982; Kawada et al., 1990). As shown in Figure 7A and B, the protein expression of $\mathrm{C} / \mathrm{EBP} \alpha$ and PPAR $\gamma$ was increased in a dose-dependent manner by $\mathrm{ZnC}$, suggesting that $\mathrm{ZnC}$ promotes adipogenesis in 3T3-L1 adipocytes through a $\mathrm{C} / \mathrm{EBP} \alpha-$ and PPAR $\gamma$-dependent pathway.

\section{CONCLUSION}

In the present study, we demonstrated that $\mathrm{ZnC}$ significantly promoted the adipogenesis of 3T3-L1 preadipocytes by enhancing the expression of the key transcription factors $\mathrm{C} / \mathrm{EBP} \alpha$ and PPAR $\gamma$ and the related adipogenic target gene aP2. Moreover, $\mathrm{ZnC}$ also stimulated the expression of GLUT4, a key regulator of insulinmediated glucose transport in adipocytes. Taken together, these findings are helpful in understanding the insulin sensitizing and adipogenic properties of $\mathrm{ZnC}$, which can be used as a novel therapeutic agent for the management of diabetes and related metabolic disorders. However, further studies are needed to assess the specific mechanism underlying the observed effects of $\mathrm{ZnC}$. 

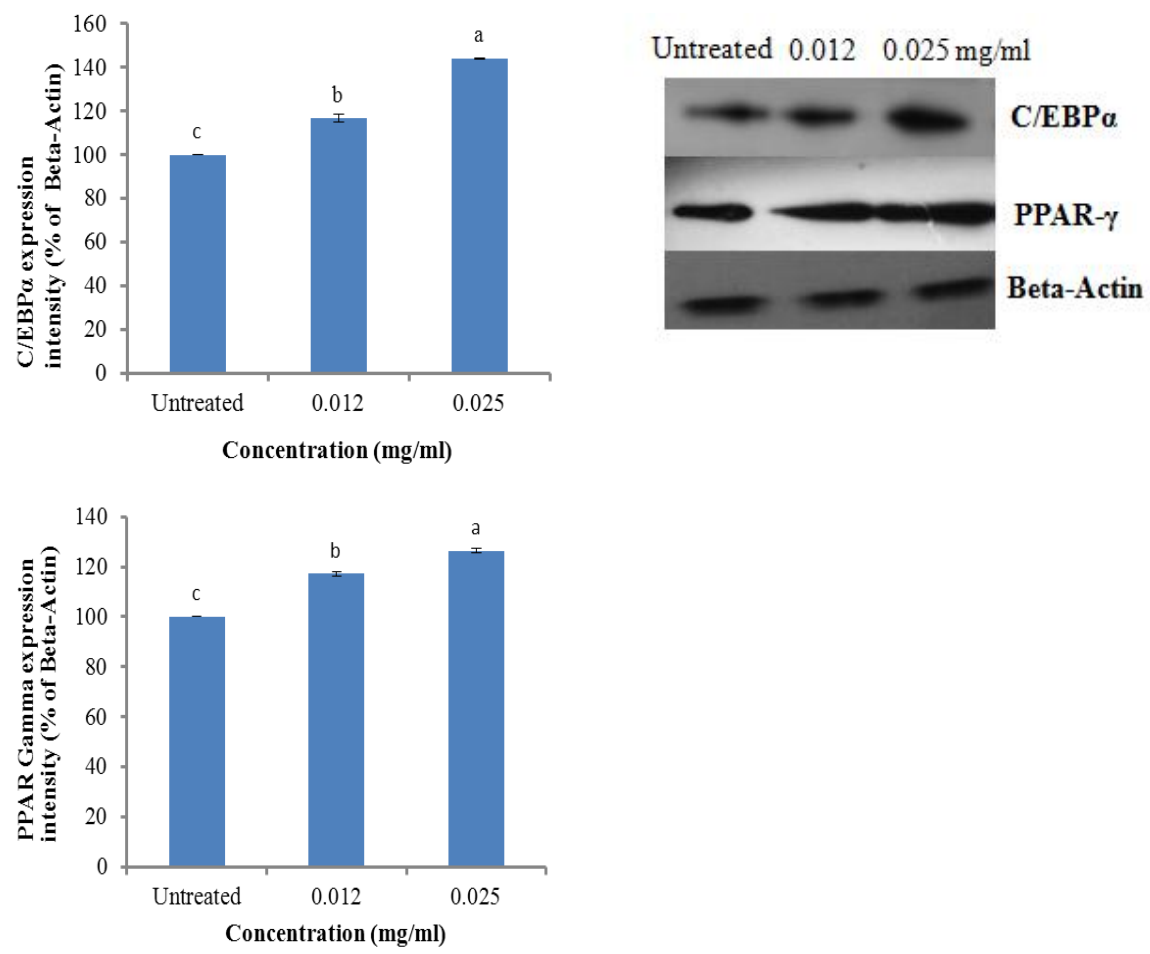

Figure 7. The effects of $\mathrm{ZnC}$ on the protein expression of $\mathrm{C} / \mathrm{EBP} \alpha(\mathrm{A})$ and PPAR $\gamma(\mathrm{B})$ in 3T3-L1 cells measured by western blot analysis. Preadipocytes were cultured in growth medium until they reached confluence and the quiescent cells were then incubated in $\mathrm{DM}$ and post-DM with $0,0.012$, and $0.025 \mathrm{mg} / \mathrm{ml}$ of $\mathrm{ZnC}$ for $8 \mathrm{~d}$, and then harvested. An equal amount $(30 \mu \mathrm{g})$ of protein from each sample was subjected to western blot analysis using antibodies for C/EBP $\alpha$ and PPAR $\gamma$. Each bar represents the mean \pm SD of three independent experiments. Bars within the same panel with different letters are significantly different $(\mathrm{p}<0.001)$.

\section{ACKNOWLEDGEMENTS}

This study was supported by a research grant from Hankyong National University for an academic exchange program in 2010.

\section{REFERENCES}

Farvid, M. S., F. Siassi, M. Jalali, and M. Hosseini. 2005. Comparison of the effects of vitamins and/or mineral supplementation on glomerular and tubular dysfunction in type 2 diabetes. Diabetes Care 28:2458-2464.

Green, H., and O. Kehinde. 1976. Spontaneous heritable changes leading to increased adipose conversion in 3T3 cells. Cell 7:105-113. doi: 10.1016/0092-8674(76)90260-9

Gregoire, F. M., C. M. Smas, and H. S. Sul. 1998. Understanding Adipocyte Differentiation. Physiol. Rev. 78:783-809.

Gunasekara, P., M. Hettiarachchi, C. Liyanage, and S. Lekamwasam. 2011. Effects of zinc and multimineral vitamin supplementation on glycemic and lipid control in adult diabetes. Diabetes Metab. Syndr. Obes. 26:53-60. doi: 10.2147/DMSO.S16691

Holman, G. D., and M. Kasuga. 1997. From receptor to transporter: insulin signalling to glucose transport. Diabetologia 40:991-1003. doi: 10.1007/s001250050780

Kawada, T., N. Aoki, Y. Kamei, K. Maeshige, S. Nishiu, and E.
Sugimoto. 1990. Comparative investigation of vitamins and their analogues on terminal differentiation, from preadipocytes to adipocytes, of 3T3-L1 cells. Comp. Biochem. Physiol. Part A. Physiol. 96:323-326. doi: http://dx.doi.org/10.1016/03009629(90)90699-S

Kiess, W., S. Petzold, M. Töpfer, A. Garten, S. Blüher, T. Kapellen, and J. Kratzsch. 2008. Adipocytes and adipose tissue. Best. Pract. Res. Clin. Endocrinol. Metab. 22:135-153. doi: 10.1016/j.beem.2007.10.002

Kinlaw, W. B., A. S. Levine, J. E. Morley, S. E. Silvis, and C. J. McClain. 1983. Abnormal zinc metabolism in type II diabetes mellitus. Am. J. Med. 75:273-277.

Kodama, M., T. Kodama, M. Murakami, and M. Kodama. 1993. Diabetes mellitus is controlled by vitamin $\mathrm{C}$ treatment. In. Vivo 7(6A):535-542.

May, J. M., and C. S. Contoreggi. 1982. The mechanism of the insulin-like effects of ionic zinc. J. Biol.Chem. 257:4362-4368.

Mizuarai, S., S. Miki, H. Araki, K. Takahashi, and H. Kotani. 2005. Identification of dicarboxylate carrier Slc25a10 as malate transporter in de Novo fatty acid synthesis. J. Biol.Chem. 280: 32434-32441. doi: 10.1074/jbc.M503152200.

Nawrocki, A. R., and P. E. Scherer. 2005. Keynote review: The adipocyte as a drug discovery target. Drug.Discov.Today. 10: 1219-1230. doi: 10.1016/S1359-6446(05)03569-5

Pittas, A. G., J. Lau, F. B. Hu, and B. Dawson-Hughes. 2007. The role of vitamin $\mathrm{D}$ and calcium in type 2 diabetes. A systematic review and meta-analysis. J. Clin. Endocrinol. Metab. 92: 
2017-2029. doi: 10.1210/jc.2007-0298

Reitman, M. L., E. Arioglu, O. Gavrilova, and S. I. Taylor. 2000. Lipoatrophy revisited. Trends. Endocrinol. Metabol. 11:410416. doi: 10.1016/S1043-2760(00)00309-X

Rosen, E. D. 2005. The transcriptional basis of adipocyte development. Prostaglandins. Leukot. Essent. Fatty Acids 73: 31-34. doi: 10.1016/j.plefa.2005.04.004.

Ross, S. R., R. A. Graves, A. Greenstein, K. A. Platt, H. L. Shyu, B. Mellovitz, B. M. Spiegelman. 1990. A fat-specific enhancer is the primary determinant of gene expression for adipocyte P2 in vivo. Proc. Natl. Acad. Sci. USA. 24:9590-9594.

Shang, W., Y. Yang, B. Jiang, H. Jin, L. Zhou, S. Liu, and M. Chen. 2007. Ginsenoside Rb1 promotes adipogenesis in 3T3-L1 cells by enhancing PPAR $\gamma$ and $\mathrm{C} / \mathrm{EBP} \alpha$ gene expression. Life. Sci. 80:618-625. doi: 10.1016/j.lfs.2006.10.021

Spiegelman, B. M., 1998. PPAR-gamma: adipogenic regulator and thiazolidinedione receptor. Diabetes 47:507-514. doi: 10.2337/diabetes.47.4.507

Spiegelman, B. M., and J. S. Fliber. 1996. Adipogenesis and obesity: rounding out the big picture. Cell 87:377-389.

Spiegelman, B. M., and J. S. Flier. 2001. Obesity and the regulation of energy balance. cell 104:531-543. doi: 10.1016/S0092-8674(01)00240-9.
Tang, X.-h., and N. F. Shay. 2001. Zinc has an insulin-like effect on glucose transport mediated by phosphoinositol-3-Kinase and akt in 3T3-L1 fibroblasts and adipocytes. J. Nutr. 131: 1414-1420.

Tontonoz, P., E. Hu, and B. M. Spiegelman. 1994. Stimulation of adipogenesis in fibroblasts by PPAR $\gamma 2$, a lipid-activated transcription factor. Cell 79:1147-1156.

Ünaleroğlu, C., B. Zümreoğlu-Karan, and Y. Mert. 2002. Zinc ascorbate: a combined experimental and computational study for structure elucidation. J. Mol. Struct. 605:227-233. doi: 10.1016/S0022-2860(01)00765-7

Willson, T. M., M. H. Lambert, and S. A. Kliewer. 2001. Peroxisome proliferator-activated receptor gamma and metabolic disease. Annu. Rev. Biochem. 70:341-367. doi: 10.1146/annurev.biochem.70.1.341.

Wu, Z., E. D. Rosen, R. Brun, S. Hauser, G. Adelmant, A. E. Troy, and B. M. Spiegelman. 1999. Cross-tegulation of C/EBP $\alpha$ and $\operatorname{PPAR} \gamma$ controls the transcriptional pathway of adipogenesis and insulin sensitivity. Mol. Cell 3:151-158. doi: http://dx.doi.org/10.1016/S1097-2765(00)80306-8

Yamauchi, T., J. Kamon, H. Waki, K. Murakami, K. Motojima, K. Komeda, and T. Kadowaki. 2001. The mechanisms by which both heterozygous peroxisome proliferator-activated receptor gamma (PPARgamma) deficiency and PPARgamma agonist improve insulin resistance. J. Biol. Chem. 276:41245-41254. doi: 10.1074/jbc.M103241200 